The effect of water stress on some traits of winter barley cultivars during early stages of plant growth

Učinak vodnoga stresa na svojstva sorti ozimoga ječma $u$ ranim fazama rasta biljke

Lalić, A., Goreta Ban, S., Perica, S., Novoselović, D., Abičić, I., Kovačević, J., Šimić, G., Guberac, V.

Poljoprivreda/Agriculture

ISSN: 1848-8080 (Online)

ISSN: 1330-7142 (Print)

http://dx.doi.org/10.18047/poljo.23.1.4

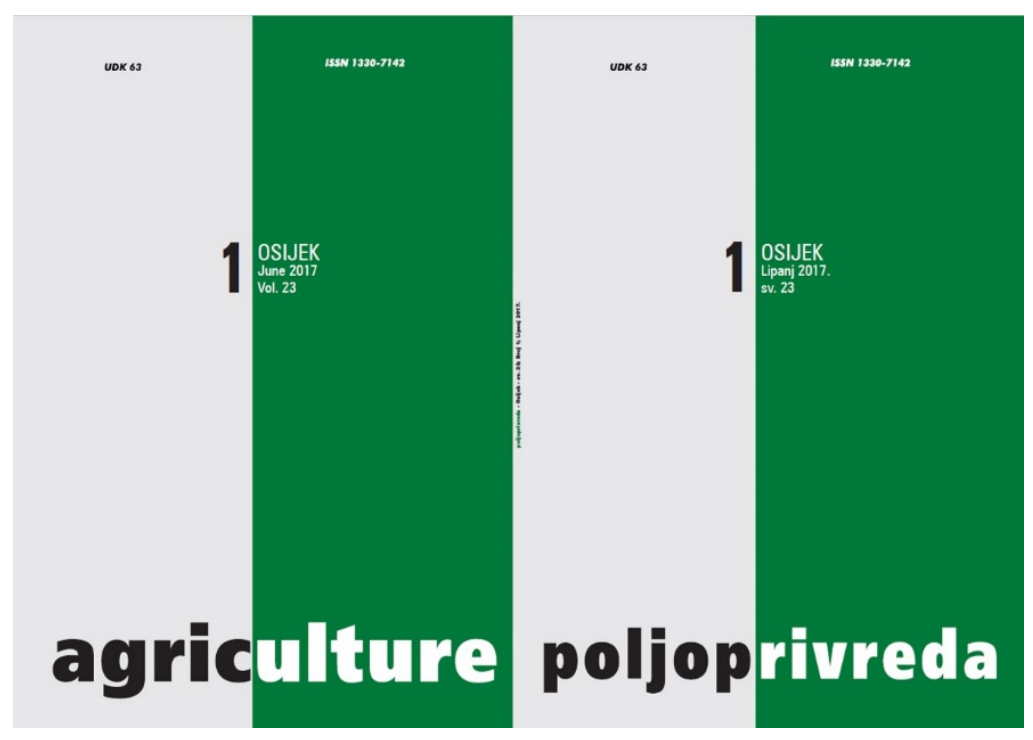

Poljoprivredni fakultet u Osijeku, Poljoprivredni institut Osijek

Faculty of Agriculture in Osijek, Agricultural Institute Osijek 


\section{THE EFFECT OF WATER STRESS ON SOME TRAITS OF WINTER BARLEY CULTIVARS DURING EARLY STAGES OF PLANT GROWTH}

Lalić, A. ${ }^{(1)}$, Goreta Ban, S. ${ }^{(2)}$, Perica, S.(3), Novoselović, D. ${ }^{(1)}$, Abičić, I. ${ }^{(1)}$, Kovačević, J. ${ }^{(1)}$, Šimić, G. ${ }^{(1)}$, Guberac, $V^{(4)}$

Original scientific paper

Izvorni znanstveni članak

\section{SUMMARY}

We conducted research on the effects of exposing barley plants to short water stress deficiency through their early growth stage. The measurements and parallel analyses of relative water content (RWC), the mass of the whole plant, leaf mass, root percentage, total root length and length of root fractions with plants exposed to stress (water deficit) and with plants which were not exposed to water deficit have been conducted. Ten varieties were included in this research. The overall average of relative water content (RWC) measured in winter barley varieties was 97.5\% under non-stressful conditions, and $66.1 \%$ under stressful conditions. An average difference between non-stressful and stressful conditions of plant mass was $61.2 \mathrm{mg}$, leaf mass $42.5 \mathrm{mg}$, RWC $31.4 \%$, root mass $18.5 \mathrm{mg}$ and total root length $129 \mathrm{~cm}$. Relative losses under effect of water stress were lower at smaller (finer) root fractions. Significant differences among the examined barley varieties cultivated under or without the water stress were found for plant mass, leaf mass, root mass, total root length and root fractions. Varieties with the lowest losses in leaf and plant mass are Titan, Arturio and Bingo. Also, the varieties Titan, Bingo and Rex had the lowest losses of root length and mass under water stress during the early growth stage.

Key-words: barley, abiotic stress, water deficiency, varieties

\section{INTRODUCTION}

The area of Eastern Croatia is considered the most important agro-ecological area for winter and spring barley production in the Republic of Croatia and is situated in a transitional area from moderate semi-arid continental type of climate to a moderate semi-humid continental Middle European climate. Characterization of this area is based on changeable weather conditions with emphasis on the amount and distribution of precipitation, which causes prevalence of shorter or longer dry periods (Kovacevic et al., 2006a, 2006b).

Abiotic stress factors such as drought, salinity, extreme temperatures, chemical toxicity and oxidative stress pose a serious threat towards plant varieties in agriculture. Abiotic stress causes grain loss for most cereals by more than $50 \%$ (Boyer, 1982). Lalić et al.
(2003) state that the barley production, within the productive area of the Republic of Croatia, is commonly exposed towards a number of stressful factors which significantly affect grain yield and quality, especially in malting barley. Authors imply that the most common biotic and abiotic stress factors in our conditions have been caused by various diseases, soil acidity, low temperatures, drought and high temperatures.

(1) Assist. Prof. Alojzije Lalić, Scientific Adviser (alojzije.lalic@poljinos.hr), Dario Novoselović, PhD, Scientific Adviser, Assoc. Prof. Josip Kovačević, Scientific Adviser, Ivan Abičić, PhD, Research Associate - Agricultural Institute Osijek, Juzno predgradje 17, HR-31000 Osijek, Croatia; (2) Smiljana Goreta Ban, PhD, Scientific Adviser - Institute of Agriculture and Tourism, Karla Huguesa 8, HR-52440 Poreč, Istria, Croatia; (3) Slavko Perica, PhD, Scientific Adviser - Institute for Adriatic Crops and Karst Reclamation, Put Duilova 11, p.p. 288, HR-21000 Split, Croatia; (4) Prof. Dr. Vlado Guberac, Josip Juraj Strossmayer University of Osijek, Faculty of Agriculture in Osijek, Vladimira Preloga 1, HR-31000 Osijek, Croatia 
Abiotic stress leads towards morphological, physiological, biochemical and molecular changes which negatively affect the plant growth and productivity. Drought, salinity, extreme temperatures and oxidative stress are commonly connected and can induce similar cell damage. For example, drought and salinization are primarily expressed as osmotic stress where they affect homeostasis and ion distribution inside the cell (Serrano et al., 2001). High temperatures accompanied by oxidative stress, salinity or drought may cause denaturation of functional and structure proteins (Smirnoff, 1998). Barley is one of the most extensively cultivated cereals in the Mediterranean region, and although water stress reduces its productivity (Lopes et al., 2004) it is, among the main temperate cereals, the one that adapts best to water shortage (Sanchez-Diaz et al., 2002).

Within this research, we explored the effects of exposing plants of 10 barley varieties to short water stress deficiency during the early stages of plant growth in order to grade them for either future recommendation and/or selection purposes.

\section{MATERIAL AND METHODS}

\section{Plant material}

The plant material used for this study included ten varieties of winter barley. Varieties Barun, Bingo, Gvozd, Lord, Titan, Rex, Spartak and Trenk are varieties of the Agricultural Institute Osijek (Croatia). Vanessa is a barley variety created in Germany (Saatzucht Josef Breun, GDBR-Herzogenaurach). Variety Arturio is created in France (Secobra). Varieties Arturio, Lord and Titan have 6-rowed type of spike.

\section{Glasshouse trial}

The trial is set up as a two-factorial glasshouse test on the Institute for Adriatic Crops and Karst Reclamation in Split through three repetitions with completely randomised block design, with genotype and water stress as main factors. Sowing of barley cultivars was conducted on March $20^{\text {th }}$ inside the pots ( $55 \mathrm{~mL}$ volume) filled with commercial organic substrate (KlasmannDielmann, Geestz, Germany) and mixed with quartz sand in 1:1 ratio. Plants started to emerge after four to six days after sowing (March 26 $6^{\text {th }}$ ); the emergence was over $90 \%$ for all varieties. Fertilization with nutrient solution $(E C=1.0, p H=5.5)$ was applied on April $4^{\text {th }}$ for stress and non-stress plants/samples and the last irrigation for stress induced plants was done 21 days after sowing (April g $^{\text {th }}$ ). Relative water content (RWC) was measured on April $13^{\text {th }}$, exactly five days after the irrigation stopped. Samples of the second leaf (by maturity) have been taken, with the central area $\left(1 \mathrm{~cm}^{2}\right)$ being cut off. One part of the leaf was immediately weighed, so we could determine the fresh leaf weight (FW). The leaf parts had been rehydrated for 20 hours inside the test tubes with distilled water and shaded; afterwards, we determined the turgid leaf weight (TW). The leaf was dried at $105^{\circ} \mathrm{C}$ until constant weight was achieved for the dry leaf weight (DW) measure. Relative water content was calculated with the following equation:

$$
\mathrm{RWC}=100 \times(\mathrm{FW}-\mathrm{DW}) /(\mathrm{TW}-\mathrm{DW}) .
$$

After seven days under water stress, at the time when signs of wilting were evident on all of the plants, we added water to retrieve turgor.

Afterwards the leaf was dried to the constant weight. The root was washed with water in order to remove the soil and sand particles from its surface, and then it was scanned (EPSON, std 1600 scanner) on 600 dots per inch (dpi), dried and later, dry weight was determined. Total root length and length by category (classes of $0.250 \mathrm{~mm}$ ) were measured with the use of programme system for root analysis (WinRhizo La 1600, Regent Instruments Inc., Quebec, Canada).

\section{Traits}

The measurements and parallel analyses of relative water content (\%), the mass of the whole plant $(\mathrm{mg})$, leaf mass $(\mathrm{mg})$, root percentage $(\%)$, total root length $(\mathrm{cm})$ and length of root fractions (RL1-RL4) (cm) with plants exposed to stress (water deficit) and with plants which were not exposed to water deficit were conducted.

Measured root length fractions by categories of root diameter (in $\mathrm{mm}$ ) are:

-RL1 - 0,001-0,250 mm,

-RL2 - 0,251-0,500 mm,

$-\mathrm{RL} 3-0,501-0,750 \mathrm{~mm}$

$-R L 4->0,751 \mathrm{~mm}$.

\section{Data analysis}

Data were analysed in Irristat for Windows (C) 2005, Version 5.0 software, where differences between varieties were calculated through Fisher's LSD test with display of aberration between stress and non-stress induced treatments $(A-B)$ for all examined traits.

\section{RESULTS AND DISCUSSION}

Relative water content (RWC) measured for 10 varieties of winter barley was $97.5 \%$ under non-stressful conditions, and $66.1 \%$ under stressful conditions (Table 1). The average leaf mass of 10 cultivars was $174.9 \mathrm{mg}$ without stress and $132.4 \mathrm{mg}$ under stress, while the entire plant mass was $238.6 \mathrm{mg}$ (non-stress) vs. 177.4 $\mathrm{mg}$ (stress). Average root mass was $63.7 \mathrm{mg}$ (nonstress) and $44.9 \mathrm{mg}$ (stress). Total root length was 776.5 $\mathrm{cm}$ (non-stress) and $647.3 \mathrm{~cm}$ (stress). An average difference between non-stressful and stressful conditions for plant mass was $61.2 \mathrm{mg}$, leaf mass $42.5 \mathrm{mg}$, RWC $31.4 \%$, root mass $18.5 \mathrm{mg}$ and total root length 129 $\mathrm{cm}$ (Tables 1 and 2). Significant differences between varieties considering stressful and non-stressful conditions were found for parameters such as plant mass, leaf mass, root mass and total root length. Significantly lower RWC ( $\leq 0.95)$ under non-stressful conditions was identified for varieties Vanessa $(95.9 \%)$ and Arturio $(96.1 \%)$, compared to RWC values of other varieties 
(Table 1). There were no significant differences of RWC values identified among examined varieties.

Sinclair and Ludlow (1985) suggest that leaf relative water content (RWC) has been proposed as a more important indicator of water status than other water potential parameters under drought stress conditions.

Table 1. Average values of analysed barley plant traits

Tablica 1. Prosječne vrijednosti svojstava biljke ječma

\begin{tabular}{|c|c|c|c|c|c|c|c|c|c|}
\hline \multirow{2}{*}{$\begin{array}{l}\text { Variety } \\
\text { Sorta }\end{array}$} & \multicolumn{3}{|c|}{ RWC (\%) } & \multicolumn{3}{|c|}{$\begin{array}{l}\text { Leaf mass (mg) } \\
\text { Masa lista (mg) }\end{array}$} & \multicolumn{3}{|c|}{$\begin{array}{l}\text { Plant mass }(\mathrm{mg}) \\
\text { Masa biljke }(\mathrm{mg})\end{array}$} \\
\hline & Non-stress (A) & Stress $(B)$ & $A-B$ & Non-stress $(A)$ & Stress $(B)$ & $A-B$ & Non-stress(A) & Stress (B) & A-B \\
\hline Arturio & $96.1^{\mathrm{b}}$ & $65.8^{\mathrm{a}}$ & 30.3 & $173.3^{\mathrm{ab}}$ & $141.1^{\mathrm{abc}}$ & 32.2 & $238.8^{\mathrm{ab}}$ & $191.6^{\mathrm{ab}}$ & 47.2 \\
\hline Barun & $98.2^{\mathrm{a}}$ & $62.3^{\mathrm{a}}$ & 35.9 & $185.6^{\mathrm{ab}}$ & $124.4^{\text {bcde }}$ & 61.2 & $261.9^{\mathrm{ab}}$ & $171.4^{\mathrm{bcd}}$ & 90.5 \\
\hline Bingo & $98.2^{\mathrm{a}}$ & $68.9^{\mathrm{a}}$ & 29.3 & $170.0^{\mathrm{abc}}$ & $133.3^{\text {abcde }}$ & 36.7 & $231.4^{\mathrm{ab}}$ & $180.6^{\mathrm{abc}}$ & 50.8 \\
\hline Gvozd & $98.0^{\mathrm{a}}$ & $65.9^{a}$ & 32.1 & $155.6^{\mathrm{bc}}$ & $123.3^{\text {cde }}$ & 32.3 & $214.6^{\text {bc }}$ & $164.2^{\text {cd }}$ & 50.4 \\
\hline Lord & $98.4^{\mathrm{a}}$ & $70.2^{\mathrm{a}}$ & 28.2 & $180^{\mathrm{ab}}$ & $116.7^{\mathrm{e}}$ & 63.3 & $241.9^{\mathrm{ab}}$ & $158.5^{d}$ & 83.4 \\
\hline Titan & $97.7^{\mathrm{a}}$ & $65.2^{\mathrm{a}}$ & 32.5 & $133.3^{\mathrm{c}}$ & $122.2^{\text {de }}$ & 11.1 & $181.8^{\mathrm{C}}$ & $166.9^{\text {cd }}$ & 14.9 \\
\hline Rex & $97.2^{\mathrm{ab}}$ & $64.6^{\mathrm{a}}$ & 32.6 & $193.3^{\mathrm{ab}}$ & $142.2^{\mathrm{ab}}$ & 51.1 & $263.2^{\mathrm{a}}$ & $190.2^{\mathrm{ab}}$ & 73.0 \\
\hline Spartak & $97.7^{\mathrm{a}}$ & $68.8^{\mathrm{a}}$ & 28.9 & $177.8^{\mathrm{ab}}$ & $132.2^{\text {abcde }}$ & 45.6 & $242.0^{\mathrm{ab}}$ & $176.3^{\text {abcd }}$ & 65.7 \\
\hline Trenk & $97.7^{\mathrm{a}}$ & $67.0^{\mathrm{a}}$ & 30.7 & $181.1^{\mathrm{ab}}$ & $138.9^{\text {abcd }}$ & 42.2 & $237.2^{\mathrm{ab}}$ & $176.5^{\text {abcd }}$ & 60.7 \\
\hline Vanessa & $95.9^{\mathrm{b}}$ & $62.2^{\mathrm{a}}$ & 33.7 & $198.9^{a}$ & $150.0^{\mathrm{a}}$ & 48.9 & $272.7^{\mathrm{a}}$ & $197.8^{\mathrm{a}}$ & 74.9 \\
\hline Average & 97.5 & 66.1 & 32.4 & 174.9 & 132.4 & 42.5 & 238.6 & 177.4 & 61.2 \\
\hline c.v. $(\%)$ & 0.93 & 8.6 & & 12.9 & 7.8 & & 11.6 & 7.2 & \\
\hline LSD & 1.56 & Ns & & 38.7 & 17.8 & & 47.6 & 22.0 & \\
\hline
\end{tabular}

$a, b, c, d, e$ - different letters denote statistically significant difference among varieties at the level of probability $p \leq 0.95$ according to Fisher's LSD test; $A-B$ represents difference between non-stress and stress induced values; ns- non-significant

The highest plant and leaf mass was realized by variety Vanessa (272.7 $\mathrm{mg}$ and $148.9 \mathrm{mg}$, respectively). Variety Titan had the least difference between plant, leaf and root mass values in plants cultivated under or without stress (Table 1 and 2). Measurements of variety Titan cultivated under stress also showed that its root mass $(44.7 \mathrm{mg})$ is similar to average root mass $(44.9$ $\mathrm{mg}$ ) among all varieties. But, bred under non-stressful conditions, the Titan showed $48.5 \mathrm{mg}$ of root mass, whereas the average root mass of all varieties is 63.7 $\mathrm{mg}$. So, Titan is well below the average value of other varieties grown without stress. Higher losses in root mass of plants grown under stress were found for varieties Barun $(29.5 \mathrm{mg})$ and Vanessa $(26 \mathrm{mg})$, with the lowest root mass loss for varieties Titan $(3.8 \mathrm{mg})$ and Bingo $(14.1 \mathrm{mg})$. Various effects of water stress on root length were also determined (Table 3.), as we found the root shortening after water stress induction, where variety Titan (26.05) and Rex (62.57) showed the lowest loss of root length, whereas Arturio (179.17) and Gvozd (165.49) showed the highest loss in root length.

Root portion in total plant mass was from $23.6 \%$ (Trenk) to $28.6 \%$ (Barun) cultivated under non-stressful conditions, and from $20.9 \%$ (Trenk) to $27.6 \%$ (Barun) under stressful conditions (Table 2). Statistically significant lower percentage of root and plant mass were displayed by variety Trenk considering variety Barun under both stressful and non-stressful conditions, and variety Trenk considering varieties Arturio and Titan under stressful cultivation conditions. The largest differences between proportional percentages of root and plant mass under stressful and non-stressful conditions can be seen in varieties Gvozd $(2.9 \%)$ and Vanessa $(3.6 \%)$, and the lowest in varieties Titan $(0.1 \%)$, Arturio $(0.7 \%)$ and Bingo $(0.2 \%)$.

Janda et al. (2008) pointed out, for wheat varieties, that PEG-treatment caused a more pronounced reduction in the weight of the shoots or roots than in their length. The reduction of biomass production was much less severe in the roots than in the shoots.

Morphological characteristics connected with drought tolerance, like the size of the root system and various leaf features, are of special concern because differences within the root system can impact the intake of nitrogen and other nutrients. Bertholdsson (1999) confirmed the fact that differences in root development and water utilization, dissimilar growth rhythm, plant morphology and yield components do affect grain yield and variability of grain protein content. Gonzales et al. (2007) indicated the presence of synergy between content of formed biomass and lower grain yield when less adaptable genotypes were exposed to water stress.

Efficiency of breeding programme by inducing selection under stressful conditions for cultivated plants was pointed out by Annicchiarico and Pecetti (1995), stating that breeding by observation, towards crop phenology imaging concerning water availability was successful in case of grain yield improvement by selecting adaptable genotypes in cases where the restricting factor is water. Botanical and agronomical plant characteristics were often used by breeders as criteria in selection mostly because they are simple to understand, use and are not expensive to analyse. 
Table 2. Average values of analysed root traits of barley plant

Tablica 2. Prosječne vrijednosti svojstava korijena ječma

\begin{tabular}{|c|c|c|c|c|c|c|c|c|c|}
\hline \multirow{2}{*}{$\begin{array}{l}\text { Variety } \\
\text { Sorta }\end{array}$} & \multicolumn{3}{|c|}{$\begin{array}{c}\text { Root mass (mg) } \\
\text { Masa korijena (mg) }\end{array}$} & \multicolumn{3}{|c|}{$\begin{array}{l}\text { Root portion (\%) } \\
\text { Udio korijena (\%) }\end{array}$} & \multicolumn{3}{|c|}{$\begin{array}{c}\text { Total root length }(\mathrm{cm}) \\
\text { Ukupna duljina korijena }(\mathrm{cm})\end{array}$} \\
\hline & Non-stress $(A)$ & Stress (B) & $A-B$ & Non-stress $(\mathrm{A})$ & Stress (B) & $A-B$ & Non- stress $(A)$ & Stress (B) & $A-B$ \\
\hline Arturio & $65.5^{\mathrm{abc}}$ & $50.5^{\mathrm{a}}$ & 15.0 & $26.9^{\mathrm{ab}}$ & $26.2^{\mathrm{a}}$ & 0.7 & $802.6^{\mathrm{abc}}$ & $623.4^{\mathrm{abc}}$ & 179.2 \\
\hline Barun & $76.4^{\mathrm{a}}$ & $46.9^{\mathrm{ab}}$ & 29.5 & $28.6^{a}$ & $27.6^{a}$ & 1.0 & $813.4^{\mathrm{ab}}$ & $677.2^{a b c}$ & 136.2 \\
\hline Bingo & $61.4^{\mathrm{bcd}}$ & $47.3^{\mathrm{ab}}$ & 14.1 & $26.3^{a b}$ & $26.1^{\text {ab }}$ & 0.2 & $854.0^{a b}$ & $727.6^{a b}$ & 126.4 \\
\hline Gvozd & $59.1^{\mathrm{bcd}}$ & $40.8^{\mathrm{ab}}$ & 18.3 & $27.5^{\mathrm{ab}}$ & $24.6^{a b}$ & 2.9 & $740.3^{\text {bcd }}$ & $574.8^{\mathrm{bc}}$ & 165.5 \\
\hline Lord & $61.9^{\mathrm{abcd}}$ & $41.8^{\mathrm{ab}}$ & 20.1 & $25.6^{\text {ab }}$ & $26.1^{\text {ab }}$ & -0.5 & $730.8^{\mathrm{bcd}}$ & $574.0^{\mathrm{bc}}$ & 156.8 \\
\hline Titan & $48.5^{\mathrm{d}}$ & $44.7^{\mathrm{ab}}$ & 3.8 & $26.9^{\text {ab }}$ & $26.7^{\mathrm{a}}$ & 0.2 & $633.1^{\mathrm{d}}$ & $607.0^{\mathrm{abc}}$ & 26.1 \\
\hline $\operatorname{Rex}$ & $69.8^{\mathrm{abc}}$ & $48.0^{\mathrm{ab}}$ & 21.8 & $26.2^{\mathrm{ab}}$ & $25.3^{a b}$ & 0.9 & $821.8^{\mathrm{ab}}$ & $759.2^{\mathrm{a}}$ & 62.6 \\
\hline Spartak & $64.2^{\mathrm{abc}}$ & $44.0^{\mathrm{ab}}$ & 20.2 & $26.3^{\mathrm{ab}}$ & $25.0^{\mathrm{ab}}$ & 1.3 & $817.0^{\mathrm{ab}}$ & $672.4^{a b c}$ & 144.6 \\
\hline Trenk & $56.0^{\text {cd }}$ & $37.6^{\mathrm{b}}$ & 18.4 & $23.6^{\mathrm{b}}$ & $20.9^{b}$ & 2.7 & $664.9^{\text {cd }}$ & $532.2^{c}$ & 132.7 \\
\hline Vanessa & $73.8^{\mathrm{ab}}$ & $47.8^{\mathrm{ab}}$ & 26.0 & $27.4^{\mathrm{ab}}$ & $23.8^{a b}$ & 3.6 & $887.2^{\mathrm{a}}$ & $724.7^{\mathrm{ab}}$ & 162.5 \\
\hline Average & 63.7 & 44.9 & 18.8 & 26.5 & 25.2 & 1.3 & 776.5 & 647.3 & 129.2 \\
\hline c.v. $(\%)$ & 13.6 & 13.6 & & 9.5 & 12.1 & & 11.0 & 15.1 & \\
\hline LSD $\mathrm{P}<95 \%$ & 14.8 & 10.5 & & 4.3 & 5.3 & & 146.1 & 167.2 & \\
\hline
\end{tabular}

$a, b, c, d$ - different letters denote statistically significant difference among varieties at the level of probability $p \leq 0.95$ according to Fisher's LSD test; $A-B$ represents difference between non-stress and stress induced values

To achieve a more precise analysis of stress effect on barley root system, we conducted fraction measurement. Under non-stressful conditions, varieties Vanessa $(887.2 \mathrm{~cm})$ and Bingo $(854.0 \mathrm{~cm})$ had the longest root length and under stressful conditions varieties Rex $(759.2 \mathrm{~cm})$, Bingo $(727.6 \mathrm{~cm})$ and Vanessa $(724.7$ $\mathrm{cm}$ ) (Table 2). Root fraction RL1 (the smallest or finest root fraction) makes the most of the root length, that is $87.1 \%$ of total root length under non-stressful conditions, and $88.5 \%$ of total root length under stressful conditions. The largest root fraction (RL4) makes the least portion of total root length, which under non-stressful conditions was $1.6 \%$, and under stressful conditions 1.1 $\%$ (Table 2 and 3). The smallest differences in root length among the finest fractions (RL1) between stressful and non-stressful conditions were established by varieties Titan $(14.9 \mathrm{~cm})$ and Rex $(33.5 \mathrm{~cm})$ (Table 3). Variety Rex had the longest length of the finest root fraction (RL1) under stressful conditions, while variety Bingo $(60.1 \mathrm{~cm})$ had the longest length of root fraction RL2. Under non-stressful conditions, Barun $(16.2 \mathrm{~cm})$ had the longest length of the largest root fraction (RL4), which reduced most under stress $(7.0 \mathrm{~cm})$ when compared to other varieties. So, the conclusion is that relative losses under the impact of water stress are lesser as the root fractions are smaller. Losses in root length at the largest fraction (RL4) were portioned $41.2 \%$, while the losses of smaller fractions were from $16 \%$ (RL1) to $31 \%$ (RL3).

Table 3. Average values of analysed barley root fractions

Tablica 3. Prosječne vrijednosti frakcija korijena ječma

\begin{tabular}{|c|c|c|c|c|c|c|c|c|}
\hline \multirow{2}{*}{$\begin{array}{l}\text { Variety } \\
\text { Sorta }\end{array}$} & \multicolumn{2}{|c|}{$\begin{array}{c}\mathrm{RL1} \\
(0.001-0.250 \mathrm{~mm})\end{array}$} & \multicolumn{2}{|c|}{$\begin{array}{c}\text { RL2 } \\
(0.251-0.500 \mathrm{~mm})\end{array}$} & \multicolumn{2}{|c|}{$\begin{array}{c}\mathrm{RL3} \\
(0.501-0.750 \mathrm{~mm})\end{array}$} & \multicolumn{2}{|c|}{$\begin{array}{c}\text { RL4 } \\
(>0.750 \mathrm{~mm})\end{array}$} \\
\hline & Non-stress & Stress & Non-stress & Stress & Non-stress & Stress & Non-stress & Stress \\
\hline Arturio & $701.8^{a}$ & $538.4^{\mathrm{abc}}$ & 66.9 abc & $56.8^{\mathrm{ab}}$ & $21.3^{\mathrm{ab}}$ & $17.4^{\mathrm{a}}$ & $10.3^{b c}$ & 8.8 \\
\hline Barun & $702.2^{\mathrm{abc}}$ & $601.4^{a b c}$ & $70.6^{\mathrm{ab}}$ & $53.1^{a b c}$ & $22.4^{\mathrm{ab}}$ & $13.2^{\mathrm{ab}}$ & $16.2^{\mathrm{a}}$ & 7.0 \\
\hline Bingo & $756.5^{\mathrm{ab}}$ & $641.9^{\mathrm{ab}}$ & $64.5^{\mathrm{abc}}$ & $60.1^{\mathrm{a}}$ & $18.5^{\mathrm{bc}}$ & $16.3^{\mathrm{ab}}$ & $12.3^{\mathrm{abc}}$ & 7.4 \\
\hline Gvozd & $645.1^{\mathrm{abcd}}$ & $507.1^{\mathrm{bc}}$ & $62.0^{a b c}$ & $45.4^{\text {bcd }}$ & $19.8^{b c}$ & $13.0^{\mathrm{ab}}$ & $11.4^{a b c}$ & 7.3 \\
\hline Lord & $629.3^{\mathrm{bcd}}$ & $509.9^{b c}$ & $65.0^{\mathrm{abc}}$ & $43.7^{\mathrm{cd}}$ & $21.6^{\mathrm{ab}}$ & $11.3^{b}$ & $12.8^{\mathrm{abc}}$ & 6.9 \\
\hline Titan & $551.8^{d}$ & 536.9 abc & $54.5^{c}$ & $47.2^{\text {bcd }}$ & $15.5^{c}$ & $13.9^{\mathrm{ab}}$ & $9.7^{b c}$ & 7.6 \\
\hline Rex & $716.1^{a b}$ & $682.6^{\mathrm{a}}$ & $69.3^{a b c}$ & $55.0^{a b c}$ & $20.6^{\mathrm{ab}}$ & $13.1^{\mathrm{ab}}$ & $13.8^{a b c}$ & 6.3 \\
\hline Spartak & $713.2^{\mathrm{ab}}$ & $596.2^{a b c}$ & $66.4^{\mathrm{abc}}$ & $53.1^{a b c}$ & $21.1^{\mathrm{ab}}$ & $14.1^{\mathrm{ab}}$ & $14.0^{\mathrm{abc}}$ & 7.1 \\
\hline Trenk & $579.2^{\text {cd }}$ & $471.0^{c}$ & $56.2^{d}$ & $40.7^{d}$ & $18.1^{b c}$ & $12.3^{\mathrm{ab}}$ & $9.3^{c}$ & 6.2 \\
\hline Vanessa & $768.4^{a}$ & $642.3^{\mathrm{ab}}$ & $76.9^{\mathrm{a}}$ & $55.9^{\mathrm{ab}}$ & $24.7^{\mathrm{a}}$ & $16.1^{\mathrm{ab}}$ & $14.8^{\mathrm{abc}}$ & 8.0 \\
\hline Average & 676.4 & 572.8 & 65.2 & 51.1 & 20.4 & 14.1 & 12.4 & 7.3 \\
\hline c.v. (\%) & 11.1 & 15.9 & 13.4 & 13.8 & 14.0 & 21.4 & 25.0 & 21.0 \\
\hline LSD & 129.1 & 156.3 & 15.0 & 12.1 & 4.9 & 5.2 & 5.3 & ns \\
\hline
\end{tabular}

$a, b, c, d$ - different letters denote statistically significant difference among varieties at the level of probability $p \leq 0.95$ according to Fisher's LSD test; ns - non-significant 
Kafawin (1998) suggests the use of root length and mass of the root dry matter as selection criteria for creating drought resistant barley varieties. However, Gorny (1996) pointed out the absence of stronger genetic correlation of barley genotypes between seminal and advent root system. Breeding varieties to increase resistance to lodging includes creation of lines with developed and healthy root system, shorter, firm and elastic stem which cannot be easily broken by the wind, with resistance to pathogens and insects that attack and weaken the root and stem.

Ceccarelli et al. (1998) concluded that the most productive lines under stressful conditions are the ones whose selection was being done not only under stress, but also the ones which originate from local varieties (landraces) collected within extremely arid areas. These findings signify an already confirmed fact that the most effective way of achieving breeders gain towards crop productivity enhancements in cultivation on less suitable areas is the use of adapted germplasm within targeted environment.

Morphological and structural adjustments, for which it has been known they provide better impact under the drought, are awns and wax coating. If present on barley, plant awns do improve the spike transpiration effectiveness (Bort et al., 1994). As it was shown, the examined winter barley varieties react differently on imposed short water stress deficiency through relative water content (RWC), plant, leaf and root mass, total root length and the length of specific root fraction (RL1-RL4), which displays the possibility to select better adjusted varieties for crop production under water shortage. It is important for breeding and selection that varietal properties are less prone to genotype by environment interaction, thus making these properties much more efficient and reliable for use through selection process.

Barley breeding, in the sense of drought resistance enhancement, should be focused on creating varieties with larger absorbance strength and water storage capacity with implementation of certain mechanisms to hamper water loss through leaf drying (Gonzales et al., 1999; Ivandić et al., 2000). These findings may serve in selection of varieties more resistant to drought stress, especially during the early growth stages and they also provide useful information about potential parental lines to be used in future breeding programs with goal to produce lines with higher tolerance to water deficit.

\section{CONCLUSION}

Through research, the measured average of RWC under non-stressful cultivation conditions was $97.5 \%$ and under stressful conditions $66.1 \%$. Influenced by water stress, the average differences in values between cultivation under stressful and non-stressful conditions were: plant mass $61.2 \mathrm{mg}$, leaf mass $42.5 \mathrm{mg}$, RWC $31.4 \%$, root mass $18.5 \mathrm{mg}$ and root length $129 \mathrm{~cm}$.

Variety Rex showed, under stressful conditions of cultivation, the largest length of the finest root fraction (RL1), while variety Bingo had the longest root fraction RL2. With Barun displaying the longest root fraction RL4 $(16.2 \mathrm{~cm})$ which, compared to other varieties, reduced the most under stress $(7.0 \mathrm{~cm})$. Relative losses under effect of water stress were less at smaller (finer) root fractions.

Significant differences between the examined barley varieties cultivated under or without stress (water deficit) were determined through factors of plant mass, leaf mass, root mass, total root length and root fractions. Varieties with the lowest losses in leaf and plant mass are Titan, Arturio and Bingo. Also, varieties Titan, Bingo and Rex had the lowest losses in root length and mass, which makes these varieties well graded for either future production recommendation and/or selection purposes against drought.

\section{REFERENCES}

1. Annicchiarico, P.I., Pecetti, L. (1995): Efficacy of a visual assessment for drought tolerance in durum wheat improvement under dryland conditions. Cereal Research Communications, 23: 95-101. A.No.: 002610114

2. Bertholdsson, N.O. (1999): Characterization of malting barley cultivars with more or less stable grain protein content under varying environmental conditions. European Journal of Agronomy, 10: 1-8. doi: http://dx.doi.org/ 10.1016/S1161-0301(98)00043-4

3. Bort, J., Febrero, A., Amaro, T., Araus, J.L. (1994): Role of awns on ear water use efficiency and grain weight in barley. Agronomie, 2: 133-139.

4. Boyer, J.S. (1982): Plant productivity and environment. Science, 218: 443-448.

doi: http://dx.doi.org/10.1126/science.218.4571.443

5. Ceccarelli, S., Grando, S., Impiglia, A. (1998): Choice of selection strategy in breeding barley for stress environments. Euphytica, 103: 307-318.

doi: http://dx.doi.org/10.1023/A:1018647001429

6. Gonzalez, A., Martin, I., Ayerbe, L. (2007): Response of barley genotypes to terminal soil moisture stress: phenology, growth, and yield. Australian Journal of Agricultural Research, 58(1): 29-37.

doi: http://dx.doi.org/10.1071/AR06026

7. Gonzalez, A., Martin, I., Ayerbe, L. (1999): Barley yield in water-stress conditions. The influence of precocity, osmotic adjustment and stomatal conductance. Field Crops Research, 62(1): 23-34. doi: http://dx.doi. org/10.1016/S0378-4290(99)00002-7

8. Gorny, A.G. (1996): Evaluation of the response to limited water, nitrogen and phosphorus supply in spring barley genotypes selected for vigorous seminal roots. Journal of Applied Genetics, 37: 11-27.

9. Ivandic, V., Hackett, C.A., Zhang, Z.J., Staub, J.E., Nevo, E., Thomas, W.T.B., Forster, B.P. (2000): Phenotypic 
responses of wild barley to experimentally imposed water stress. Journal of Experimental Botany, 51: 2021-2029.

doi: http://dx.doi.org/10.1093/jexbot/51.353.2021

10. Irristat for Windows (C) 2005, Version 5.0. International Rice Research Institute DAPO Box 7777, Metro Manilla, Phillipines.

11. Janda, T., Cseplo, M., Nemeth, Cs., Vida, Gy., Pogany, M., Szalay, G., Veisz, 0. (2008): Combined effect of water stress and infection with the necrotrophic fungal pathogen Drechslera tritici-repentis on growth and antioxidant activity in wheat. Cereal Research Communications, 36(1): 53-64.

doi: http://dx.doi.org/10.1556/CRC.36.2008.1.6

12. Kafawin, O.M. (1998): Seed size and water potential effects on germination and early growth of two barley cultivars. Dirasat Agricultural Sciences, 25: 335-342.

13. Kovacevic, V., Banaj, D., Kovacevic, J., Lalic, A., Jurkovic Z., Krizmanic M. (2006a): Influences of liming on maize, sunflower and barley. Cereal Research Communications, 34(1): 553-556.

14. Kovacevic, J., Lalic A. Kovacevic, V., Banaj, D. (2006b): Response of barley to ameliorative fertilization. Cereal Research Communications, 34(1): 565-568.
15. Lalić, A., Kovačević, J., Bićanić, V., Vincetić, D. (2003): Urod i kakvoća zrna, pogodnosti i teškoće u proizvodnji pivarskog ječma u Republici Hrvatskoj. Svijet piva, 45: 6-12.

16. Sinclair, T.R., Ludlow, M.M., (1985): Who thaught of plants thermodynamics? The unfulfilled potential of plant water potential. Aust. J. Plan Physiol., 12: 213-217.

doi: http://dx.doi.org/10.1071/PP9850213

17. Lopes, M.S., Nogues, S., Araus, J.L. (2004): Nitrogen source and water regime effects on barley photosynthesis and isotope signature. Funct. Plant Biol., 31: 9951003.

18. Sanchez-Diaz, M., Garcia, J.L., Antolin, M.C., Araus, J.L. (2002): Effects of soil drought and atmospheric humidity on yield, gas exchange, and stable carbon isotope composition of barley. Photosythetica, 40: 415-421.

19. Smirnoff, N. (1998): Plant resistance to environmental stress. Curr Opin Biot., 9: 214-219.

doi: http://dx.doi.org/10.1016/S0958-1669(98)80118-3

20. Serrano, R., Rodriguez-Navarro, A. (2001): Ion homeostasis during salt stress in plants. Curr. Opin. Cell Biol., 13: 399-404.

doi: http://dx.doi.org/10.1016/S0955-0674(00)00227-1

\section{UČINAK VODNOGA STRESA NA SVOJSTVA SORTI OZIMOGA JEČMA U RANIM FAZAMA RASTA BILJKE}

\section{SAŽETAK}

U radu su istraživani učinci izlaganja biljaka ječma abiotskome stresu (nedostatku vode) u njegovim ranim fazama rasta. Izvršena su mjerenja i usporedna analiza relativnoga sadržaja vode u biljci (RWC), mase biljke u cjelini, mase lista, udjela korijena, ukupne dužine korijena te dužine pojedinih frakcija korijena (VL1-VL4) kod biljaka izloženih stresu (nedostatku vode) i biljaka bez vodnoga stresa na 10 kultivara ozimoga ječma. $U$ istraživanjima je izmjeren prosječan RWC u nestresnim uvjetima uzgoja $97,5 \%$, a u uvjetima stresa $66,1 \%$. Prosječna razlika između nestresnih i stresnih uvjeta kod mase biljke iznosila je 61,2 mg, mase lista 42,5 mg, RWC 31,4\%, mase korijena 18,5 mg i ukupne dužine korijena $129 \mathrm{~cm}$. Ustanovljeno je da su relativni gubitci pod utjecajem vodnoga stresa manji što su frakcije korijena sitnije. Pod utjecajem vodnoga stresa najmanje gubitke mase lista $i$ biljke imale su sorte Titan, Arturio i Bingo. Na temelju najmanjih gubitaka prouzročenih stresom mase korijena i dužine korijena, najpovoljniju reakciju na vodni stres u ranim fazama razvoja biljke imale su sorte Titan, Bingo i Rex.

Ključne riječi: ječam, abiotski stres, nedostatak vode, sorte

(Received on 24 January 2017; accepted on 10 May 2017 - Primljeno 24. siječnja 2017.; prihvaćeno 10. svibnja 2017.) 